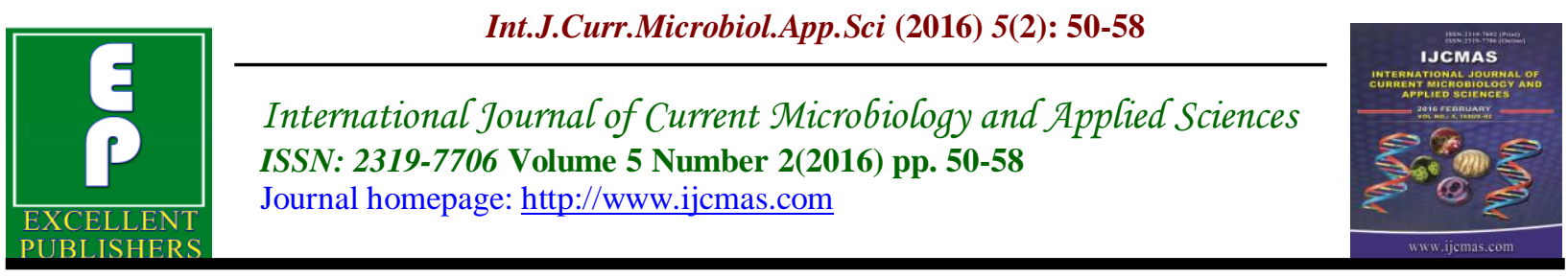

Original Research Article

doi: http://dx.doi.org/10.20546/ijcmas.2016.502.005

\title{
Screening of Indigenous Cyanobacterial Species from Darlaghat Cement Mining Area of Himachal Pradesh
}

\author{
Rani Nisha* and Anand Sagar \\ Department of Biosciences, Himachal Pradesh University, Shimla, India \\ *Corresponding author
}

\begin{abstract}
A B S T R A C T
Keywords

Waste land, Biofertilizer, Cyanobacteria, Nostoc

\section{Article Info}

Accepted:

09 January 2016

Available Online:

10, February 2016

Land sources are becoming limited as the population size is increasing day by day. Due to mining and related activities the soil and water resources gets damaged, contaminated and polluted. The overall environment gets disturbed and looses its green cover exposing more area to erosion. To meet the challenge, the focus is on to reclaim the degraded land and understands the complexities and interactions of soil biological system and agro-ecosystem as a whole. Bio-fertilizers play a very significant role in improving soil fertility. Lack of region specific strains is one of the major constraints in popularizing the bio-fertilizer as these are not only crop specific but soil and region specific too. Therefore, in the present investigation indigenous species of cyanobacteria was isolated from cement mining wasteland. The physico-chemical analysis of the mined and agricultural fields revealed structurally unstable and poor status of micro-and macro nutrients. The diversity indices of the area also revealed the presence of only few species belonging to genus Nostoc (5 species), Anabaena (1 sp.), Cylindrospermum (1 sp.), Hapalosiphon (1sp.). The genus Nostoc was found to be most dominant with 5 isolates and $62 \%$ occurrence followed by other genera represented by one species and $12.5 \%$ of occurrence.
\end{abstract}

\section{Introduction}

Himachal Pradesh known as Dev-bhumi is a fruit bowl of India and agriculture is chief occupation and main source of income as well as employment for the people residing in the State. Rapid industrialization, mining, urbanization and non sustainable development have aggravated the cause of water and soil pollution in the state, which has not only degraded the quality of water used for irrigation and drinking purposes but also affected the flora \& fauna. The ecology of the system has been degraded a lot which has also disturbed and imbalanced the natural equilibrium between the living and non-living components of the environment.

The state has four big cement plants which include ACC at Barmana, Ambuja Cements Limited at Darlaghat, JP Cements at Bagha and CCI at Rajban, which have an aggregate production capacity of 12.06 million tonnes. In the rural areas the farming community is severely suffering due to the cement plants resulting in the change in their cropping 
systems and shift in their food security mechanism with rising vulnerability (Vineet et al., 2011). Mining operations from open cast to cave has resulted in ecological problems from erosion, formation of skinholes, biodiversity loss, and heavy metal and organic contamination of ground water and surface water worldwide (Kraus and Wiegand, 2006). In India, gradual increase in such landscapes due to intensive mining activities has endangered the forest productivity (Saxena and Chatterji, 1988a,b). These changes have adverse impacts both social as well as economic for the nearby communities who are dependent on the region's natural resources for large portion of their income.

Eco-restoration of such mined areas by some foresters has been reported in Himachal Pradesh but the field experimentation involving various components is still lacking which need to be taken up in a comprehensive manner. Thus, development of suitable technology package for reclamation of mined areas through a systematic research programme is needed. With growing demand for safe and healthy food, long term sustainability and concern on environmental pollution associated with indiscriminate use of chemical in the agriculture, organic farming using biofertilizer has emerged as an important priority area (Nisha et al. 2016). Use of beneficial microorganisms like vesicular arbuscular mycorrhizae (VAM), blue green algae (BGA), Rhizobium, Azotobacter, Phosphate solublizing microorganism (PSM) etc. show greater potential for reclamation of silica mined areas (Setiadi, 2000).

Lack of region specific strains is one of the major constraints in popularizing the biofertilizers as these are not only crop specific but soil and region specific too. Therefore the present study is aimed to explore the indigenous cyanobacterial flora that can be used further in restoring, rehabilitating mined areas.

\section{Materials and Methods}

\section{Sampling Area}

The soil samples were collected from six villages viz. adjoining Mining site of Chakhru $\left(\mathrm{S}_{1}\right)$, agricultural fields of Chakhru $\left(\mathrm{S}_{2}\right)$, Kashlog $\left(\mathrm{S}_{3}\right)$, Chandi $\left(\mathrm{S}_{4}\right)$, Gyana $\left(\mathrm{S}_{5}\right)$ and Kararaghat $\left(S_{6}\right)$ village $(10 \mathrm{~km}$ from mining site representing control) of Kashlog mining area, Darlaghat, District Solan, Himachal Pradesh. The area spread over an area of about $4.88 \mathrm{Km}$ and is about $10 \mathrm{Km}$ from the National Highway-88. It falls between the Latitude $31^{\circ} 13,50.5^{\prime \prime}$ to $31^{\circ}$ $15^{\prime} 28^{\prime \prime} \mathrm{N}$ and Longitude $76^{\circ} 55^{\prime} 38^{\prime \prime}$ to $77^{\circ}$ 0 ' 9.5" $\mathrm{E}$ and at an elevation of 1280-1740 $\mathrm{m}$ above mean sea level.

\section{Sample Collection}

Soil samples were collected from different depths after removing the top soil i.e. $10 \mathrm{~cm}$, $15 \mathrm{~cm}, 20 \mathrm{~cm}$ below the surface. The samples were collected and transferred to laboratory in a good quality, air tight and clean plastic bags for analysis. The soil was cleaned, air dried, crushed, homogenized and sieved, and then stored in air tight bags for analysis.

\section{Soil Analysis}

Soil samples were analyzed for physical and chemical characteristics viz water holding capacity, bulk density, porosity, particle density, pH, EC, Organic Carbon, macro $(\mathrm{N}, \mathrm{P}, \mathrm{K})$ and micro nutrients $(\mathrm{Cu}, \mathrm{Fe}, \mathrm{Zn}$, $\mathrm{Mn})$. Electrical conductivity of saturation extract (ECe) and $\mathrm{pH}$ of saturation paste of soils were measured using conductivity 
meter and $\mathrm{pH}$ meter, respectively. Total organic carbon (TOC) was determined by Black and Walkley's rapid dichromate titration method. Total Kjeldahl nitrogen (TKN), were estimated following Allen et al. (1986). Phosphate was estimated by molybdenum blue complex formation method Exchangeable sodium and potassium were estimated by Flame photometer and micronutrients $(\mathrm{Cu}, \mathrm{Fe}, \mathrm{Zn}$, $\mathrm{Mn}$ ) were estimated using Atomic Absorption Spectrophotometer (Allen et al., 1986).

\section{Isolation and identification}

Cyanobacterial strains were isolated from fresh soils using serial dilution $\left(10^{-2}\right)$ following standard culturing and purification techniques (Kaushik, 1987) using N-free BG-11 medium. Cultures were incubated at $28 \pm 3^{0} \mathrm{C}$ under continuous illumination of 3000 Lux using cool white fluorescent lamps. They were examined microscopically for various structural features for identification (Desikachary, 1959). Unialgal cultures obtained were maintained at $25^{\circ} \mathrm{C}$ for further studies. Percentage occurrence of cyanobacterial species was determined using following formula

$\%$ occurrence of Cyanobacterial Species $=$ No. of a species/total no. of species $\times 100$

\section{Estimation of Species Diversity Indices}

Shannon-Wienner diversity index and Simpson's index of diversity were calculated using the following formulae.

\section{$\mathbf{S}$}

Shannon-Wienner index, $\mathrm{Hs}=-\sum(\mathrm{Pi}) * \ln (\mathrm{Pi})$ i=1

Where, Hs = Symbol for the diversity in a sample of S species or kind.
$\mathrm{S}=$ The number of species in the sample.

$\mathrm{Pi}=$ Measures the relative abundance of $\mathrm{i}^{\text {th }}$ species or kinds $=$ ni $/ \mathrm{N}$

$\mathrm{N}=$ The total number of individuals of all kinds.

ni $=$ The number of individuals of $i^{\text {th }}$ species.

$\ln =\log$ to base 2 .

Simpson's Index of Diversity = 1- D

Where, $\mathrm{D}=\sum(\mathrm{n} / \mathrm{N})^{2}$

$\mathrm{n}=$ The total number of organisms of a particular species.

$\mathrm{N}=$ The total number of organisms of all the species.

\section{Results and Discussion}

\section{Analysis of Physico-Chemical Properties of Soil}

The analysis of physico-chemical properties of the six villages of cement mining area is represented in the table 1-2. The soil $\mathrm{pH}$ ranged from 8.22-7.31 indicating alkaline nature of the soil of mining area. The decrease in the value was observed when we move from the mining area towards agricultural fields of normal land. The same trend was observed for organic status and water holding capacity of the soil. The soil of the area is more porous, having high bulk and particle density and low water holding capacity. The soil is organically poor and has normal electrical conductivity as compared to the non mining agricultural land. The mining activities cause sudden perturbation in the process and properties of soil leading to soil degradation (Lal, 1997), alteration in structural properties of soil, loss 
of organic carbon (Akala and Lal, 2001), reduction in total porosity and increase in bulk density (Chong et al., 1986).

The increase in bulk density can be attributed to low organic matter in the soil as compared to agriculture fields. Mined spoils have higher bulk density and coarse fragment, lower porosity, clay content and water holding capacity then the normal soil (Masoodi and Soni, 1999). Studies of Panwar (1999) at district Solan, Himachal Pradesh revealed that mining activity leads to depletion of nutrients contents and organic matter.

Limestone mining area is characterized by poor soil quality in terms of low nutrient level and reduced nutrient cycling capacity. Exploitation of limestone further resulted in disturbance of large tract of land and after mining the fertility status of the soil changed to large extent. The overall productivity of soil is reduced due to unavailability of micro and macronutrients (Singh and Jamaluddin, 2010). Accumulation of heavy metals and their toxic effects on biota in such mined lands have also been reported (Misra et al., 1990). The disruption in the plant-soilmicrobe system causes alteration in the biogeochemical cycles has further aggravates the problems of such marginal lands.

The available nitrogen content is slightly more in mining soil of Chakru village as compared to other agricultural fields indicating variable distribution of plant, grass and vegetation cover of the soil in the investigated area. Vimmersted et al., 1989 also reported an increase in $\mathrm{N}$-content in calcareous mined spoils. Several other workers Wali and Freeman, 1973; Russel and La Roi, 1986, also reported an increase in $\mathrm{N}$ - content in such lands.
There is a significance increase in available phosphorus and $\mathrm{K}$ in soils of agricultural fields of the area as we move from mined land towards normal fields. This increase may be due to increase in vegetation cover and agricultural inputs in the form of chemical fertilizers. The microorganisms present in rhizosphere also enhanced these nutrients possible through rock weathering and made available to the growing crops (Singh and Jamaluddin, 2010, 2011).

The overall concentration of available micro and macro nutrients is very low in the mining soil and increased as we move from mining site to other agricultural fields. The concentration of $\mathrm{Cu}$ and $\mathrm{Zn}$ is found to be more in mined soil of Chakru and Kashlog village as compared to the agriculture fields of the same and adjacent village (table-2). There are reports of high concentration of $\mathrm{Zn}$ among other trace elements in coal mined spoils as observed by Jastrow et al., 1981 and Stucky et al., 1980. At their low to moderate concentrations these heavy metals are beneficial to human health (Conesa et al., 2009).

\section{Isolation and Diversity of Cyanobacterial Species}

A total no of eight species of cyanobacteria were isolated and purified from the mining area of Kashlog mining site of Darlaghat, District Solan, Himachal Pradesh. These species belongs to 2 different orders viz Nostocales and Stigonematales of class Cyanophyceae. In order Nostocales the 7 isolates belongs to 3 different genera i.e. Nostoc (5 species), Anabaena (1 sp.), Cylindrospermum (1 $\quad$ sp.). One cyanobacterial isolate belongs to order Stigonematales and genus Hapalosiphon (1sp.). 
Table.1 Some Physico- chemical Properties of the Soil (six locations) from Kashlog Cement Mining* Area

\begin{tabular}{|l|l|l|l|l|l|c|c|}
\hline S. No & $\begin{array}{l}\mathbf{p H} \\
\mathbf{1 : 2}\end{array}$ & $\begin{array}{l}\text { EC } \\
\mathbf{d S m}\end{array}$ & $\begin{array}{l}\text { Organic } \\
\text { Carbon } \\
(\boldsymbol{\%})\end{array}$ & $\begin{array}{l}\text { Water } \\
\text { holding } \\
\text { Capacity } \mathbf{( \% )}\end{array}$ & $\begin{array}{l}\text { Bulk } \\
\text { Density } \\
\left(\mathbf{g} / \mathbf{c m}^{\mathbf{3}}\right)\end{array}$ & $\begin{array}{c}\text { Particle Density } \\
\left(\mathbf{g} / \mathbf{c m}^{\mathbf{3}}\right)\end{array}$ & $\begin{array}{c}\text { Porosity } \\
(\mathbf{\%})\end{array}$ \\
\hline $\mathbf{S}_{\mathbf{1}}$ & 8.22 & 0.13 & 0.51 & 30.5 & 1.15 & 1.34 & 12.18 \\
\hline $\mathbf{S}_{\mathbf{2}}$ & 8.12 & 0.156 & 1.08 & 35.5 & 1.03 & 1.23 & 14.26 \\
\hline $\mathbf{S}_{\mathbf{3}}$ & 7.42 & 0.356 & 2.38 & 42.5 & 1.27 & 1.53 & 14 \\
\hline $\mathbf{S}_{\mathbf{4}}$ & 7.37 & 0.258 & 1.57 & 57.5 & 1.17 & 1.33 & 12 \\
\hline $\mathbf{S}_{\mathbf{5}}$ & 7.36 & 0.262 & 2.17 & 60 & 1.13 & 1.30 & 13 \\
\hline $\mathbf{S}_{\mathbf{6}}$ & 7.31 & 0.230 & 2.37 & 60 & 1.13 & 1.30 & 13 \\
\hline
\end{tabular}

*Mining site of Chakhru $\left(\mathrm{S}_{1}\right)$, agricultural fields of Chakhru $\left(\mathrm{S}_{2}\right)$, Kashlog $\left(\mathrm{S}_{3}\right)$, Chandi $\left(\mathrm{S}_{4}\right)$, Gyana $\left(\mathrm{S}_{5}\right)$ and Kararaghat $\left(\mathrm{S}_{6}\right)$ village $(10 \mathrm{~km}$ from mining site representing control)

Table. 2 Available Macro and Micro Nutrients Concentration in the Soil (six locations) of the Kashlog Cement Mining* Area

\begin{tabular}{|l|c|c|c|c|c|c|c|c|}
\hline \multirow{2}{*}{ S.No } & \multicolumn{8}{|c|}{ Available Macro and Micro Nutrients (Kg/ha) } \\
\cline { 2 - 9 } & $\mathbf{N}$ & $\mathbf{P}$ & $\mathbf{K}$ & $\mathbf{N a}$ & $\mathbf{C u}$ & $\mathbf{F e}$ & $\mathbf{M n}$ & $\mathbf{Z n}$ \\
\hline $\mathbf{S}_{\mathbf{1}}$ & 200.7 & 11.20 & 23.26 & 2.93 & 2.77 & 13.94 & 5.16 & 2.79 \\
& \pm 0.7 & \pm 0.5 & \pm 0.3 & \pm 0.3 & \pm 0.06 & \pm 0.2 & \pm 0.18 & \pm 0.3 \\
\hline $\mathbf{S}_{\mathbf{2}}$ & 131.7 & 13.44 & 15.5 & 2.4 & 1.18 & 10.78 & 5.95 & 1.50 \\
& \pm 0.75 & \pm 0.5 & \pm 0.5 & \pm 0.2 & \pm 0.08 & \pm 0.4 & \pm 0.15 & \pm 0.03 \\
\hline $\mathbf{S}_{\mathbf{3}}$ & 169.5 & 62.0 & 46.76 & 3.1 & 3.39 & 9.47 & 8.15 & 4.22 \\
& \pm 0.6 & \pm 1.05 & \pm 0.4 & \pm 0.25 & \pm 0.02 & \pm 0.5 & \pm 0.2 & \pm 0.32 \\
\hline $\mathbf{S}_{\mathbf{4}}$ & 263.5 & 77.66 & 61.6 & 3.1 & 2 & 20.22 & 8.57 & 3.71 \\
& \pm 0.6 & \pm 0.7 & \pm 0.5 & \pm 0.26 & \pm 0.03 & \pm 0.3 & \pm 0.15 & \pm 0.02 \\
\hline $\mathbf{S}_{\mathbf{5}}$ & 194.46 & 85.46 & 93.4 & 2.4 & 1.49 & 14.15 & 8.04 & 4.29 \\
& \pm 0.7 & \pm 0.7 & \pm 0.6 & \pm 0.17 & \pm 0.02 & \pm 0.15 & \pm 0.11 & \pm 0.03 \\
\hline $\mathbf{S}_{\mathbf{6}}$ & 175.36 & 93.36 & 39.8 & 2.33 & 1.06 & 20.37 & 9.65 & 2.84 \\
& \pm 1.06 & \pm 0.7 & \pm 0.5 & \pm 0.2 & \pm 0.17 & \pm 0.38 & \pm 0.09 & \pm 0.2 \\
& & & & & & & \\
\hline
\end{tabular}


Table.3 Species Evenness and Diversity of Cyanobacterial Species in Cement Mining Area

\begin{tabular}{|c|c|c|c|c|}
\hline Location & Total Isolates & Species Evenness & \multicolumn{2}{|c|}{ Diversity Indices } \\
\cline { 3 - 4 } & 8 & 0.79 & Shannon & Simpson's \\
\hline $\begin{array}{c}\text { Kashlog Cement } \\
\text { Mining area }\end{array}$ & 8 & 1.1 & 0.565 \\
\hline
\end{tabular}

Fig.1 \% Occurrence of Cyanobacterial Species in Kashlog Cement Mining Area

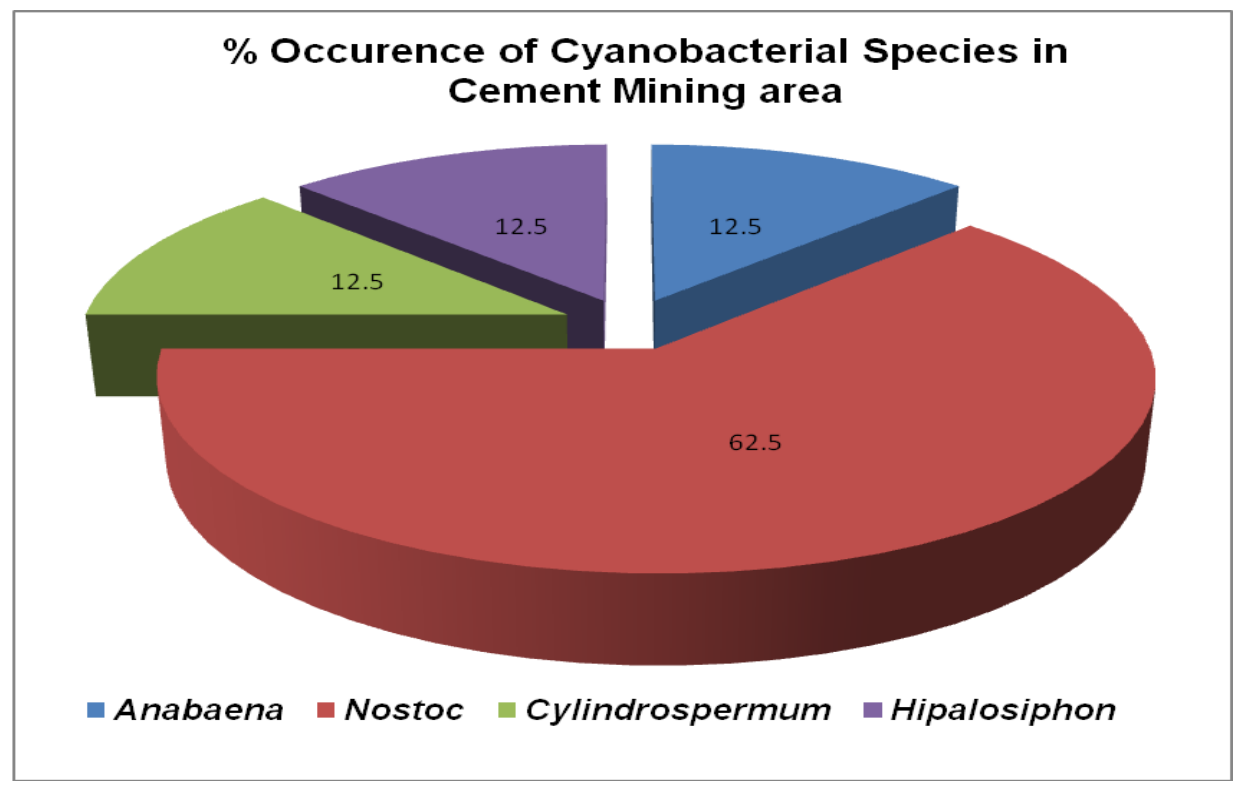

The genus Nostoc was found to be most dominant with 5 isolates and $62 \%$ occurrence (Fig-1) followed by other genera represented by one species and $12.5 \%$ of occurrence. Table 3 shows the species evenness and diversity indices for cyanobacterial species present in the Kashlog Cement mining area. There is low value of Shannon and Simpson Diversity indices and species evenness in the area as shown in the table.

Cyanobacteria are prokaryotic oxygenic phototrophs found in almost every conceivable habitat on earth (Ferris et al., 1996). They have wide distribution ranging from aquatic to terrestrial habitat as well as in extreme environment such as hot springs, deserts and Polar Regions (Whitton and Pott, 2000) due to their adaptation (Spores and Akinetes) to drought and desiccation.These organisms are estimated to have occurred as long ago as 2600 to 3500 million years, based on fossil records, organic biomarkers and genomic sequence analysis (Schopf, 2000; Hedges et al., 2001). Cyanobacteria play an important role in global nitrogen cycle, increase availability of $\mathrm{P}$, enhance the organic matter and can prevent soil erosion. Many species of Calothrix, Nostoc, Tolypothrix and Westiellopsis were reported only on moist shaded soil surfaces (Venkataraman et al., 1974) or on dry exposed substratum 
(Pattanaik and Adhikary, 2002). Cyanobacterial species present in the dry soil belongs to genera Oscillatoria, Phormidium, Microcoleus, Nostoc, Calothrix, Aulosira, Fischerella, Westiellopsis and Hapalosiphon (Tirkey and Adhikary, 2005).

Cyanobacterial biofertilizers have been reported to be very useful in ameliorating various physico-chemical properties of marginal soils and the EPS produced by the cyanobacteria seems to play an important role (Nisha et al., 2007).

Agriculture is chief occupation of people in Himachal Pradesh and is the main source of income as well as employment. With growing demand for safe and healthy food, long term sustainability and concern on environmental pollution associated with indiscriminate use of chemicals in the agriculture, organic-farming using biofertilizer has emerged as an important priority area. Application of organic manures particularly bio-fertilizers is the only option to improve the soil organic carbon for sustenance of soil quality and future agricultural productivity. Therefore, in the present study indigenous cyanobacterial species were isolated to be used as biofertilizer in reclamation of such marginal land.

\section{Acknowledgements}

Authors are thankful to UGC, New Delhi, India for financial assistance in the form of UGC-PDFW fellowship as well as to the Chairperson, Department of Biosciences, H.P.U. Shimla for providing Lab. facilities.

\section{References}

Akala, V.A., Lal, R. 2001. Soil organic carbon pools and sequestration rates in reclaimed mine soils in Ohio. $J$. Environ. Qual, 30: 2098-2104.

Allen, S.E., Grimshaw, H.M., Rowland, A.P. 1986. Chemical analysis. In: Moore, P.W. and Chapman, S.B. (Eds.). Methods in Plant Ecology. Blackwell Scientific Publication, Oxford, pp. 285-344.

Chong, S.K, Becker, M.A., Moore S.M., Weaver G.T. 1986. Characterization of reclaimed mined land with and without topsoil. J. Environ. Qual, 15:157-160.

Conesa, H. M., Moradia, A.B., Robinson, B. H., Kuhne, G., Lehmann, E., Schulin, R. 2009 Response of native grasses and Cicer arietinum to soil polluted with mining wastes: Implications for the management of land adjacent to mine sites. Environmental and Experimental Botany, 65:198-204.

Desikachary, T.V., 1959. Cyanophyta. Indian Council of Agricultural Research, New Delhi. p. 686

Ferris, M.J., Muyzer, G., Ward, D.M. 1996. Denaturing gradient gel electrophoresis profiles of $16 \mathrm{~S}$ rRNAdefined populations inhabiting a hot spring microbial mat community. Appl. Environ Microbio,. 62, 340-346.

Hedges, S.B., Chen, H., Kumar, S., Wang, D.Y., Thompson, A.S., Wantabe, H., 2001. A genomic timescale for the origin of eukaryotes. BMC Evol Biol, 1: 4 .

Jastrow, J.D., Zimmerman, C.A., Dvorak, A.J., Hichman, R.R. 1981. Plant growth and trace element uptake on acidic coal refuse amended with lime or fly ash. J. Environ. Quality, 10: 1416.

Kaushik, B.D., 1987. Laboratory methods for blue green algae. Associated Publishing Company, New Delhi. pp. 171.

Kraus, U., Wiegand, J. 2006. Long-term 
effects of the Aznalcollar mine spillheavy metal content and mobility in soils and sediments of the Guadiamar river valley (SW Spain). Science of the Total Environment, 367(2-3): 855-871.

Lal, R. 1997. Soil quality and sustainability In : Lal R. et al. (eds.), Methods of assessment of Soil Degradation, CRC Press, Boca Raton, FL, 17-30.

Masoodi, T.H., Soni, P. 1999. Physical properties of limestone mine restored for forest land use. Indian journal of forestry, 22: 30-36.

Misra, A.K., Patnaik, R., Thatoi, H.N., Padhi, G.S. 1990. Assessment of beneficial soil microflora of iron and chromite mine over burdened mine area of orissa- an index of sudy of heavy metal toxicity of soil fertility. In: Environmental Impact of Industrial and Mining Activity, Patnaik, L.N. (ed.), New World Environmental Series, Ashish Publishing House, New Delhi, India, pp: 263-269.

Nisha, R., Kaushik, A., Kaushik, C.P. 2007. Effect of indigenous cyanobacterial application on structural stability and productivity of an organically poor semiarid soil. Geoderma, 138, 49-56.

Nisha, R., Joshi, M., Sagar, A. 2016. Algal management: methods of soil management. In: Microalgae: windows of opportunity, Sharma, M., S., Bansal, D., Chauhan, A. (eds.), SBW publishers, pp:307 (in press).

Panwar, P.1999. Vegetational survey of mined areas afforestration techniques for their rehabilitation. M.Sc. thesis. Department of Silviculture and Agroforestry. Dr. Y.S. Parmar University of Horticulture and forestry, Nauni, Solan (H.P.) .94p.

Pattanaik, B., Adhikary, S.P. 2002. Bluegreen flora on archeological monuments of India. Bull. Bot. Surv.
India, 44: 61-74.

Rusell, W.B., Roi, G.B. La. 1986. Natural vegetation and ecology of abandoned coal mined land, Rocky Mountain Foothills, Alberta, Canada. Canadian J. Botany, 64: 1286-1298.

Saxena, S.K., Chatterji, P.C. 1988a. Ecological imbalance caused by mining in Rajasthan and their Restoration. In: Mining and Environment in India. (Joshi and Bhattacharya eds.). HRG Publication Series, Nainital, India. 223-241

Saxena, S.K., Chatterji, P.C. 1988b. Mining activity and creation of wasteland in western Rajasthan. In: Wasteland development and their utilization. (K.A. Shankarnarayan ed.), Scientific Publisher, Jodhpur, 41-61

Schopf, J.W., 2000. The fossil record: tracing the roots of the cyanobacterial lineage. In: Whitton BA, Potts $\mathrm{M}$ (eds) The ecology of cyanobacteria. Kluwer, Dordrecht, pp 13-35

Setiadi, Y. 2000. Mycorrhizal seedling production for enhancing rehabilitation of degraded forest in Indonesia. Workshop of Forest Restoration for Wildlife Conservation, Chiang Mai, Thailand. Jan 30 - Feb 4, 2000.

Singh, A. K. , Jamaluddin. 2010. Role of microbial inoculants on growth and establishment of plantation and natural regeneration in limestone mined spoils. World Journal of Agricultural Sciences, 6 (6): 707-712.

Singh A. K., Jamaluddin. 2011. Status and diversity of arbuscular mycorrhizal fungi and its role in natural regeneration on limestone mined spoils. Biodiversitas, 12 (2) 107-111.

Stucky, D.J., Bauer, J.H., Lindsey, T.C. 1980. Restoration of acidic mine spoils with sewage sludge. I. Revegetation and Reclamation Res., 
33: 129-139.

Tirkey, J., Adhikary, S.P. 2005.

Cyanobacteria in biological soil crusts of India. Current Sci., 89, 515- 521.

Venkataraman, G.S., Goyal, S.K., Kaushik, B.D., Roychoudahury, P. 1974. Algae: Form and Function, Today and Tomorrows, New Delhi, pp. 183-186.

Vimmersted, J.P., House, M.C., Larson, M.M., Kasile, J.D., Bishop, B.L. 1989. Nitrogen and carbon accretion on Ohio coal mine spoils: influence of soil forming factors. Landscape Urban Planning, 17: 99-111

Vineet, K. S., Singh, S. R., Kumar, K. 2011.
The impact of cement Industries on the cropping system of adjoining areas. J.of farm science 1, 1:96-104.

Wali, M.K., Freeman, P.G. 1973. Ecology of some mined areas in North Dakota. In: Some Environmental Aspects of Stripmining in North Dakota, Wali, M.K. (ed.), Geological Survey and Education Services, North Dakota, pp: 25-47.

Whitton, B.A., Potts, M., 2000. The ecology of cyanobacteria, their diversity in time and space. Kluwer Academic Publ, The Netherlands.

\section{How to cite this article:}

Rani Nisha and Anand Sagar. 2016. Screening of Indigenous Cyanobacterial Species from Darlaghat Cement Mining Area of Himachal Pradesh. Int.J.Curr.Microbiol.App.Sci.5(2): 5058. doi: http://dx.doi.org/10.20546/ijcmas.2016.502.005 